\title{
Swiss Architectural Origins, Le Corbusier, and the Pātaka of Lake Horowhenua (1845)
}

\author{
Peter Wood, School of Architecture, Victoria University, Wellington
}

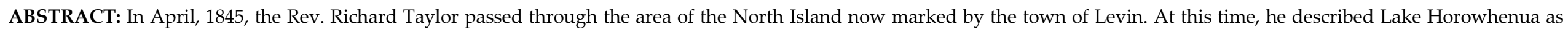

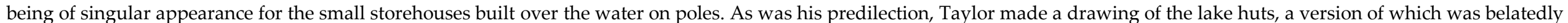

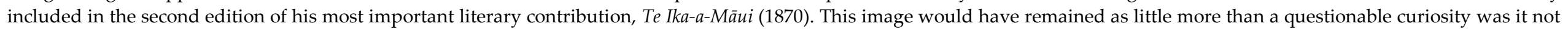

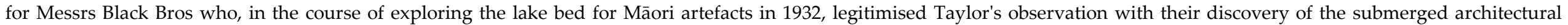

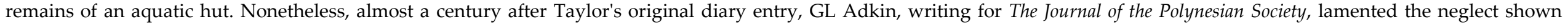

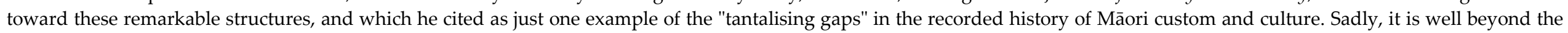

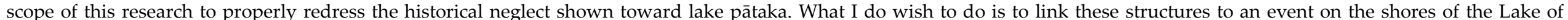

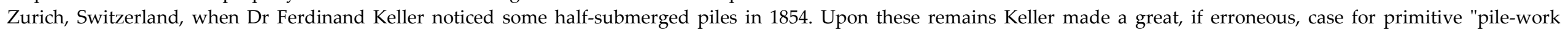

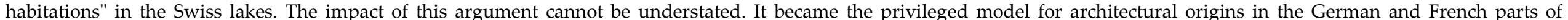

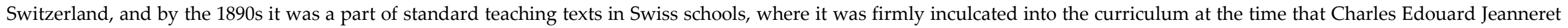

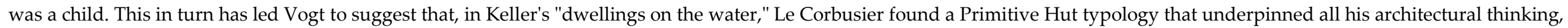

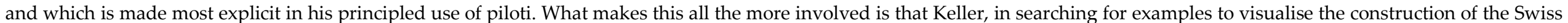

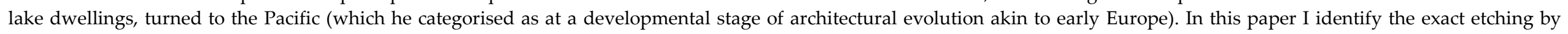

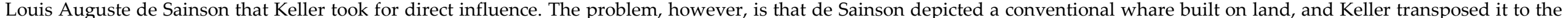

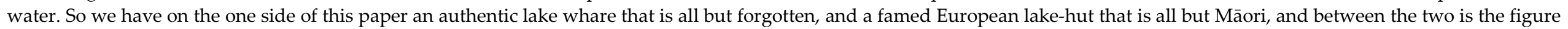
of Le Corbusier who may or may not have unknowingly based one on his major innovations on influences found in the pātaka of Lake Horowhenua.

Of all the colonial figures that explored New Zealand in the 1840s none has left us with quite the idiosyncratic graphic record as that provided by the Rev Richard Taylor. Taylor arrived at Paihia, Bay of Islands, on the 10th March 1939, and almost immediately established his professional pattern of peripatetic evangelising that would take him all over the North Island, all the while keeping a diary in which he made both written and drawn notations. These recordings provide an especially compelling chronicle of his encounters with Māori. Many of these concern the architectural world of Māori at that time, and, if we extend to Taylor's drawings an open mind concerning representational accuracy, we find a far more rich and varied compendium of architectural objects than most accounts would suggest. This is not the place to explore Taylor's record of Māori architecture to any degree of thoroughness, but I will take this opportunity to test the validity of one particularly evocative scene in which Taylor recorded the remarkable spectacle of elevated store-houses - pātaka - standing across Lake
Horowhenua. ${ }^{1}$ His notes at that time are in no way detailed, but they do associate these pātaka to the activities of eel fishing. I am not aware of any similar pātaka that were sited in a lake either before or after Taylor's encounter. Moreover, much later Taylor would present an entirely different thesis for this apparently isolated architectural example. In this paper I wish to test the legitimacy, associations and implications of this extraordinary image that could just as easily be forgotten as an

\footnotetext{
1 Taylor "Lake Buildings in Horowhenua."
} 
historical oddity.

With his 1843 appointment to succeed John Mason at the Whanganui Mission, and subsequent evangelical responsibilities, we can be certain that Taylor passed through this area many times. The first specific reference we have dates to 20 April 1844 when he recorded dining at Horowhenua as a guest of a senior chief, and receiving "'"some very fine eels"'" (to which he reciprocated with rice and sugar). ${ }^{2}$ The gift of eels, and identification of a nearby lake whose name "'"signifies the sinking of the land","3 suggest a fertile wetland. We know that Taylor was again at Lake Horowhenua ${ }^{4}$ on 19 April 1845 when he entered into his diary the following

2 Taylor quoted, Adkin "Former Food Stores (Pataka) in Lake Horowhenua" p 186.

${ }^{3}$ Taylor quoted, Adkin "Former Food Stores (Pataka) in Lake Horowhenua" p 186. From "whenua," meaning land, and "horo" whose use encompasses aspects of falling, crumbling, breaking and landslides. Maori Dictionary n.p.

4 "Afterwards we came to Horowhenua, a lake three miles long and near one mile wide in the shape of a crescent: the approach to it was through very bad swamp, and the whole trembled so much that it gave the idea that the ground might sink into the depth of the lake with its superincumbent weight."

Taylor quoted, Adkin "Former Food Stores (Pataka) in Lake Horowhenua" p 186.

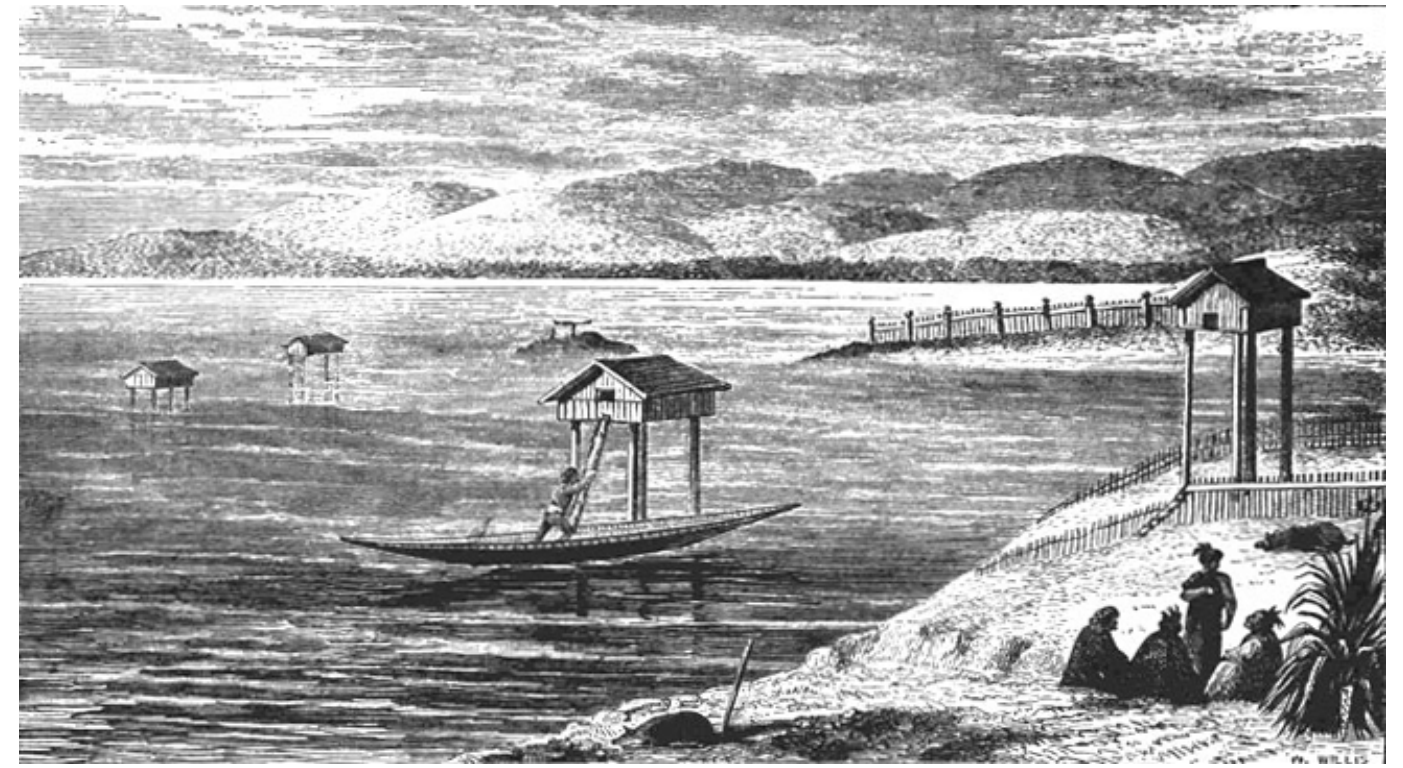

Figure 1: Taylor Te Ika-a-Maui (1870) p 17, republished Adkin "Former Food Stores" p 184

description:

The lake has a singular appearance from a number of little storehouses being built in every part of it on poles and surrounded with a kind of fence which are used for storing eels taken here in large quantities. ${ }^{5}$

To accompany this description Taylor added a small sketch into his diary and this is where it remained, all but forgotten as a small addendum to his travels. However, this is not to suggest that Taylor ever forgot about them,

${ }^{5}$ Taylor quoted, Adkin "Former Food Stores (Pataka) in Lake Horowhenua" p 186. simply that this particular drawing remained hidden in their diary location. It was not until 1870 that Taylor revisited the lake pātaka with the inclusion of a refined version in the second edition of his major contribution on Māori culture and history, Te Ika-a-Maui, in 1870.

Taylor's lake pātaka image was subsequently given a further boost by Elsdon Best, in 1916, when he published a version "based" on Taylor's Te Ika-a-Māui illustration, in his work on Māori storehouses, but even then Best was careful to write: 
This picture is of interest as the only one we possess of storehouses so situated, for such a situation for a pataka was uncommon. ${ }^{6}$

And there the mystery of the Lake Horowhenua pātaka might have slipped quietly out of our historical record were it not for the efforts of GL Adkin. In 1942 The Journal of the Polynesian Society published Adkin's attempt to geographically locate the pātaka described by Taylor. In this essay Adkin analysed Taylor's Te Ika-a-Māui illustration in order to ascertain the exact location from which the picture was made. ${ }^{7}$ The more salient point from Adkin for this paper is his statement that the "old-style" food houses had been recently "discovered" by Messrs Black Bros, of Levin, whose amateur archaeological explorations of the area had revealed "the sunken remains of one of these interesting structures was located toward the northern end of the lake, 20 yards north-east of the islet

${ }^{6}$ Best Maori Storehouses and Kindred Structures p 10. ${ }^{7}$ Adkin concludes that the image in execution was a double perspective derived from two viewing positions, the first being from a position on an eastern brow and the second from near the Waipata islet. This shift allowed Taylor to fully portray the foreground pātaka against a recognizably accurate background. Adkin "Former Food Stores (Pataka) in Lake Horowhenua" p 185.

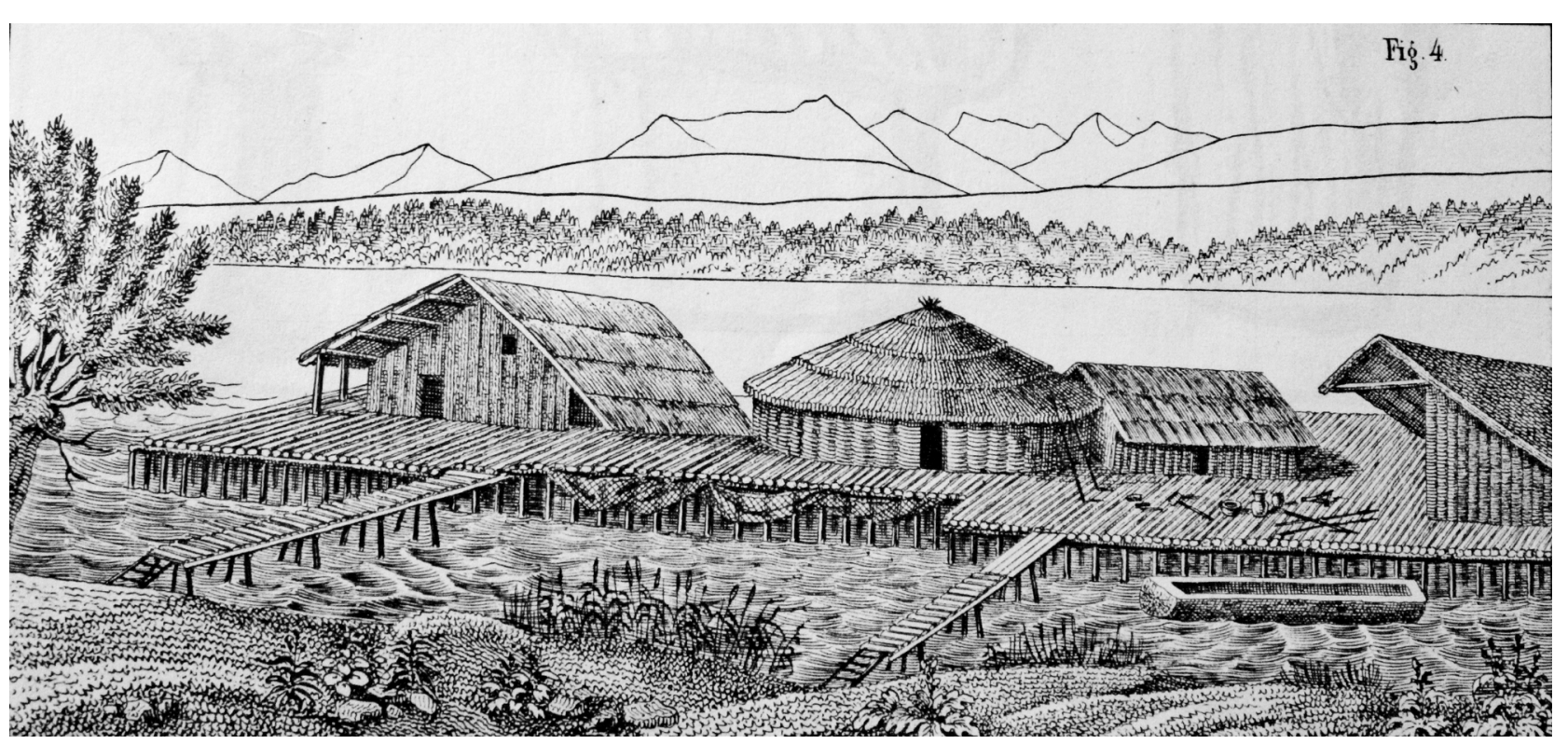

Figure 2: Ferdinand Keller "The discovery of the lake dwellings in the Lake of Zurich" Mittheilungen der Antiquarischen Gesellschaft in Zürich $(1854,1858)$

called Namu-Iti." 8 This, in Adkin's mind at least, proved the previous existence of at least four lake pātaka, "but there were probably more."9

At this point the narrative of Lake Horowhenua's aquatic storehouses is evidentially thin but historically compelling. Richard Taylor first sketched the pātaka over

${ }^{8}$ Adkin "Former Food Stores (Pataka) in Lake Horowhenua" p 186

${ }_{9}$ Adkin "Former Food Stores (Pataka) in Lake Horowhenua" p 186. the lake surface in 1845 , and then formalised the image in a published form in 1870. The revival of the scene by Best in 1916 may well have been the impetus for the explorations of Black Bros, who in turn were a clear influence on Adkin's desire to geographically quantify the accuracy of the image. However, this timeline brings its own curiosity.

Te Ika-a-Māui was first published in 1855 without the Lake Horowhenua pātaka, so Taylor's decision to revive a minor, 25-yearold sketch for inclusion in the revised edition 
of 1870 (in what is thought of as his most important work) is worth consideration. It is my view that Taylor's decision to redraw, and then publish, the lake pātaka scene so long after its first recording was not accidental and has everything, to do with archaeological research that had occurred on the shores of Lake Zurich between the time that had passed between editions of Te Ika-a-Māui. This is supported by a presentation on "Lake Pas" by Taylor to the Wellington Philosophical Society in 1872 in which he recalled the Horowhenua scene with its "watas"; "and seeing the natives ascend to them from their canoes by means of a notched pole." 10

Immediately this is a more romanticallycharged description than he has given before, and the reason for this is revealed in the following extraordinary statement:

When afterwards, in 1854, the remains of villages were discovered in the Swiss lakes, and similar ones, called crannogues, in Ireland, it then struck me that the same practice had formerly prevailed in New Zealand, and especially in the Horowhenua Lake, and that the watas I had seen there were but remnants of the custom. ${ }^{11}$

\footnotetext{
10 Taylor "On New Zealand Lake Pas" n.p.
} ${ }^{11}$ Taylor "On New Zealand Lake Pas" n.p.
From a modern perspective this would seem a most improbable connection, but it is actually very consistent with the rise of interest in ethnographic and geological origins that occurs in the nineteenth century. The exact manner in which Taylor might have become familiar with literature in this area eludes me, but the canonical work of the period is Charles Lyell's 1863 book, The Geological Evidences of the Antiquity of Man, in which Lyell attempted to redress prominent scientific questions of his time.

This publication can rightly be considered a seminal text in the formation of modern archaeology, but its relevance to this paper is limited to two smaller moments of interest to a New Zealand architectural audience. In the first of these Lyell makes a brief but informed mention of the Wellington earthquake of 1855 that contributed significantly to the preference for timber houses in the capital's early colonial period. The second connection is more oblique and implicates Taylor's conclusions on the lake pātaka. The first illustration Lyell utilises in Geological Evidences depicts, according to its title, "A Village Built on Piles in a Swiss Lake." The caption explains in more detail that it is a "restored" image by Dr F Keller derived from sketches made by Dumont D'Urville of "similar habitations in New Guinea."12 I will explain how and why Keller could use a New Guinean model presently, but at this point I want to draw attention to the hut on the furthest left which has a striking resemblance, not to a Micronesian dwelling, but to a Māori whare. To be even more specific, it is the hut found in Louis Auguste de Sainson's decidedly terrestrial depiction of a whare at Tolaga Bay in 1833. But it is necessary to tease this story out to appreciate the full repercussions.

That Lyell was able to use the Swiss pile village to introduce his book says everything about how popular the image had already become by the $1860 \mathrm{~s}$. According to Vogt, by the end of that century it presented a view so universally accepted that it could be found in the books issued to every 9-12 year old student in Switzerland. Vogt's interest in this small point is anything but minor. In this he recognises that the schoolboy CW Jeanneret more widely known today as Le Corbusier would have been fully exposed to this romanticised model of Swiss architectural origins. To further simplify Vogt's argument,

${ }^{12}$ Lyell The Geological Evidences of the Antiquity of Man "Plate 1: A Village Built on Piles in a Swiss Lake." 
he goes on to conclude that Le Corbusier's practice of elevating buildings on piloti owes its existence precisely to the influence of Keller's search for vernacular architectural origins.

In 1854 Ferdinand Keller, a Swiss archaeologist, had an epiphany. On the shore at Meilen he observed half-decayed piles in an area where pottery and stone tools had been recently uncovered. His inspirational leap was to see in the watery remains a model of stoneage settlement that consisted of "pile work habitations." That same year he published his thesis as Die keltischen Pfahlbauten in den Schweizerseen (The Celtic Lake Dwellings in the Swiss Lakes) in which he wrote:

in the earliest epoch of dawning history, groups of families dwelt in huts which they had built not on dry land but on the shallow shoreline on top of pile-work. ${ }^{13}$

Keller's position was nothing short of a radical revision of European civilisation, and, in the subsequent frenzy of lake edge exploration he inspired, many other sites of pile remains were "discovered." The only setback was that Keller was utterly wrong. Subsequent analysis challenged, and eventually contradicted

\footnotetext{
${ }^{13}$ Keller quoted, Vogt Le Corbusier p 18.
}

Keller's case. Today the accepted scientific explanation for the waterlogged piles is also the most obvious: between historical occupation, and the point at which Keller noticed them, the lakes had increased in size, thus expanding their shoreline and absorbing foundations that had otherwise been completely terrestrial.

But the fact that this refutation took 75 years shows just how compelling Keller's model was entrenched in the Swiss psyche. Even so, we might wonder how it could be quite that embedded. This answer, too, is plainly simple. The brilliance of Keller's propagation of his lake dwelling hypothesis was to give it a derivation image that captured the popular imagination of the Swiss. As Vogt tells it, this small drawing became, overnight, the most popular image in both the German and French speaking parts of Switzerland and remained so for many decades, being a favoured scene for commercial calendars and academic research alike. ${ }^{14}$

It is not hard to see the appeal. Four huts in a variety of types are elevated over the surface of a lake on a large pile platform. In the

${ }^{14}$ Vogt Le Corbusier p 227. foreground footbridges link the platform to the shore, and in the background a mountain range rises upward. For the Swiss it would have been an image of topographical familiarity populated with an utterly exotic architectural configuration.

This pictorial derivation occurs as a part of a pictorial table in Keller's Die keltischen Pfahlbauten that illustrated the archaeological evidence of the shoreline discovery. However, unlike the accompanying images this one departs from the methodological rigor of observational diagramming and provides a pictorial recreation of what the lake dwellings would have looked like. This recreation is, in any sense, a bold step for a thesis based on scientific evidence. That he was prepared to take it was due to an equally bold assumption - that the newly documented Pacific represented a point in its cultural, social and architectural evolution akin to a primordial Europe, and therefore it demonstrated a comparable standard for any pictorial recreation irrespective of its geographical distance. The practice of transposing values Vogt calls it a retrograde ethnological inference was a common enough approach in the nineteenth century, but it is important to remember that it involves supplanting a 
mythological approximation of first origins with a pragmatic approximation, in which specific, ethnographic and architectural information can be lifted verbatim and relocated into a European historic narrative. ${ }^{15}$ Keller's intellectual presumptions on this issue are apparent when he writes:

Since a similar state of culture always elicits ... similar needs and consequentially produces similar tools for life's various purposes, we can derive a clear idea of the state of civilisation of the colony at Meilen most plausible when we compare its products ... with descriptions we owe to the travelers who have visited those peoples ... situated outside ... of the region of European civilization. ${ }^{16}$

Of course, this strategy also depended upon having a visual description. As a guide in explaining this Keller continues "[w]e have based the drawing ... on the views of the village of Doreï reported by Dumont dUrville."17 Vogt is more specific in sourcing this visual reference to Voyage de la Astrolabe execute par ordre du Roi pendant les années 18261827-1828-1829. Histoire du voyage (1830-1833) on which the expedition draftsman was Louis Auguste de Sainson.

\footnotetext{
${ }^{15}$ Vogt Le Corbusier p 228.

${ }^{16}$ Keller quoted, Vogt Le Corbusier p 232.

${ }^{17}$ Keller quoted, Vogt Le Corbusier p 229.
}

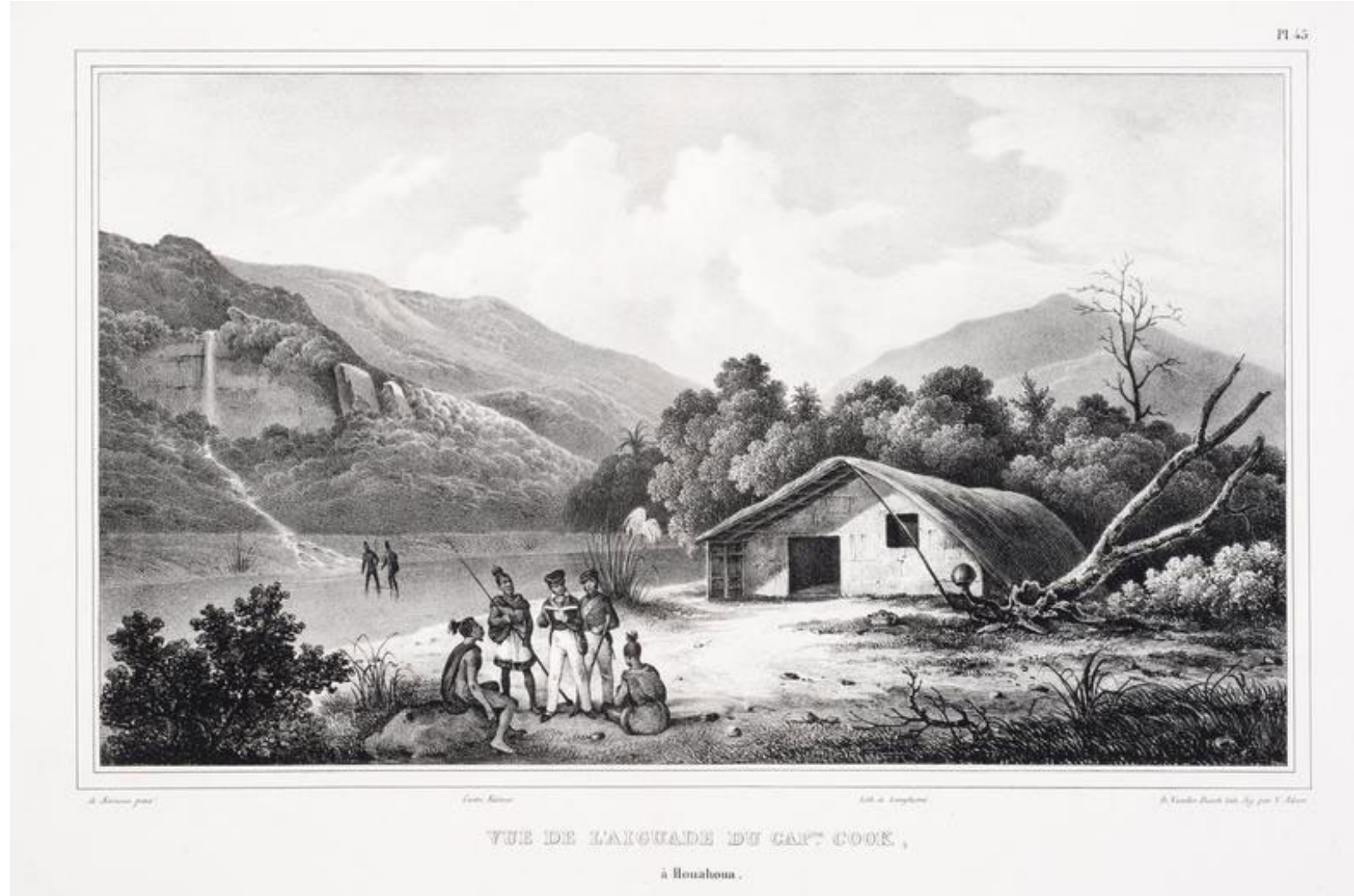

Figure 3: Louis Auguste de Sainson and Victor Adam Vue de l'Aiguade di Cap.ne Cook, a Houahoua, [view of the watering place of Captain Cook, at Houahoua (Uawa - Tolaga Bay)] 1833 Auckland Art Gallery Toi o Tamaki Accession Number 2009/3/7

Unfortunately it is also beyond the scope of this paper to give this image, and its Pacific influence, the full critique it deserves. ${ }^{18}$ What I

${ }^{18}$ What I would note in passing is that while I agree with Keller's observations on the nature and influence of de
Sainson's Astrolobe recordings I do not agree that the derivation was as simple as he suggests.

do want to unpack is the significance of the hut whose formal appearance seems so 
specifically that of a Māori whare. ${ }^{19}$ In the thatched gable roof, low eaves, door with what appear as carved panels, apparent post and beam construction, and the small smoke hole, we have a convincing example of a whare from the mid-nineteenth century.

But as my claim is that Keller used an image of a whare to contradictory effect in his argument, it is incumbent upon me to test this. So I would begin by looking at the ways in which this particular hut form in Keller's inference does not fit a typical whare model in order to legitimise any conclusions.

There are two important inconsistencies in this regard. The first is the asymmetry to the gable eave, with the right-hand eave dropping to touch the platform. The second is the open porch wall to the left, which, while "proving' the post and beam assemblage departs from the enclosed whare porch that operates as a partial extension of the interior. Together these create an open-closed relationship that orientates this hut along the linear axis of the platform, and out into the lake. This

${ }^{19}$ It is important here to mention that, in citing a second travel report, Keller quoted Captain James Cook on the aborigines of New Zealand for an entire page. Vogt Le Corbusier $\mathrm{p} 232$. challenges the primacy of the gable façade in a fundamental way. However, while we might take those differences as evidence that this is not a whare, my view is that these anomalies actually locate a specific whare. Namely the one Louis Auguste de Sainson's depicted in Tolaga Bay, 1827. There a number of versions of this view, but as my argument depends upon the understanding that it needed to be available to Keller, I will take the most formally composed example; Louis Auguste de Sainson and Victor Adam's Vue de l'Aiguade du Cap.ne Cook, à Houahoua, [View of the watering place of Captain Cook, at Houahoua (Uawa - Tolaga Bay)] dating to 1833.

The telling traits that correlate de Sainson's view with Keller's inference are the asymmetrical gable, seemingly open porch, and reorientation to the water.

The first of these points offers the most compelling visual comparison. De Sainson was considered a draftsman of some accuracy, so his portrayal of the right-hand eave fading into the ground line, beneath a collapsing tree, was probably quite careful and may indicate a whare in decline.

The second issue relates to the open porch. In de Sainson's depiction the porch is enclosed but the exposure of the post and beam construction allows for easy comparison.

Together the eave and porch contribute to exactly the same reorientation across the façade that is apparent in Keller's model, and with the same implications to an aquatic orientation. In the case of Keller to the lake, with de Sainson across the river to a waterfall.

If these two huts are isolated from their scenes, and placed side by side, it is actually very difficult to distinguish between their essential pictorial qualities. Indeed, there is a particularly remarkable correlation of the perspectival inaccuracy on the right hand, the gable ridge that leaves both huts with identically contorted roof planes. Keller, I suggest with confidence, took his model for this Swiss lake-dwelling from de Sainson, but it now becomes necessary to agree the painfully obvious fact that the whare in Tolaga Bay is not only placed on land, but it can be observed through the doorway that it even has a earthen-floor interior. However, it is consistent with Buchli's appraisal of what he terms the "armchair anthropologists" who reassembled images from earlier sources to make cases for the inherent similarity of 
cultures and their social and material forms, despite widely different temporal, geographic and climatic contexts,

simply reassembling images from earlier sources in addition to the ones they themselves caused to be made. ${ }^{20}$

But even more ironic is the suggestion that, in this misrepresentation of a typical whare, Keller seems to be completely oblivious to the Māori practice of elevated huts - pātaka - that would have so conveniently fitted his poledwelling hypothesis.

This leaves Keller's pictorial narrative in an uncomfortable position. It is now agreed that his vision of pre-historic Swiss lake-dwellings was completely wrong. Nonetheless, Vogt has shown that this point was completely lost on Le Corbusier for whom Keller's model provided a vernacular origin for his use of piloti. At the same time, in light of the Tolaga Bay whare, it is more than feasible that Keller knew he was misrepresenting Pacific architecture when he composed his pictorial recreation. And that knowledge, in turn, thoroughly emasculates Rev Richard Taylor's moment of inspiration where he connected the

${ }^{20}$ Buchli An Anthropology of Architecture p 37. whare of Lake Horowhenua to a global pattern of pre-historic origins in lake-dwelling huts.

And yet there exists a pattern of associations structured, if not on fact, then on effective combination of wanton desire and ignorant serendipity. Le Corbusier's use of piloti has nothing to do with pātaka. But in the flawed logic of associations, Le Corbusier could have found a perfect model here (albeit far removed from Swiss nationalism), and Taylor's yearning to place his youthful observations of Māori culture into emergent nineteenth-century ethnographic scholarship suffered only for being incorrect.

Rev Richard Taylor's sketches of early New Zealand do provide an unparalleled visual record of candid observations. Taylor needs to be recognised as an enthusiast diarist and not a trained artist or draughtsman. His travels through New Zealand in the 1840s was theologically motivated, and we can be confident that he saw himself passing through a land fitting his desire for pious service. His drawings, inevitably, will reflect this, and consequentially we need to extend to his work some tolerance regarding their accuracy, and some degree of suspicion regarding his motivation in selecting subject matter. It is reasonable to wonder if Taylor made the same romantic assumptions regarding origins and occupation as Keller and similarly saw what he wanted to find. In his enthusiasm he never stopped to ask the most revealing of questions: how does one actually build pātaka over water?

As a structural expression the pātaka is highly reliant on the bedding of its posts to maintain its physical integrity. As Sundt has explained, Māori architectural construction of this period finds its stability from the technique of deeply burying the column posts. ${ }^{21}$ This system allows every post to be an upright cantilever providing independent vertical and horizontal support. This system is achieved by digging a sloping trench that allows the post to be slid or rolled into place and then lifted from one end with the trench backfilled to buttress. The most practical example of this is the single column pātaka in which the structural logic relies on the integrity and depth of the post's foundation. Taking this as a principle the next question is a simple one: how do you dig a hole in a lakebed, which is a far less predictable, accessible, stable or practical

\footnotetext{
${ }^{21}$ Sundt Whare Karaia pp 165-166.
} 
building site than earth. Even if we take a best-case scenario of swampy terrain the problem of digging, erecting and stabilising a freestanding post quickly becomes implausible. Working in similar conditions it is modern construction practice to drive piles into waterlogged ground but there is no evidence that pre-contact or colonial period Māori had at their disposal the necessary technology to drive piles.

The obvious way to account for building lake bed pātaka is to abandon it altogether. When locating the site of Taylor's pātaka image Adkin makes mention of the difficulties presented by the recession of the lake edge (by as much as a quarter of a mile in his estimation). ${ }^{22}$ The implication here is that the shoreline of Lake Horowhenua was no more stable over the short-term than Lake Zurich was over the long-term. This leads to the simple explanation that the lake pātaka Taylor drew were not constructed over the water at all, but were merely claimed by an unstable lake level, and then claimed again as evidence for Lake Horowhenua standing alongside Lake Zurich as kindred examples of romantic

${ }^{22}$ Adkin "Former Food Stores (Pataka) in Lake Horowhenua" p 186. vernacular origins that never existed. 


\section{REFERENCES}

Adkin G. L. "Former Food Stores (Pataka) in Lake Horowhenua" The Journal of the Polynesian Society (1942) 51(3): 181-186.

http://www.jps.auckland.ac.nz/document//Volume_51_1942/Volume_ 51\%2C_No._3/Former_food_stores_in_Lake_Horowhenua\%2C_by_G. _L._Adkin\%2C_p_181-186/p1\#

Best, Elsdon Maori Storehouses and Kindred Structures: Houses, Platforms, racks, and Pits used for Storing Food, etc. Wellington: Government Printer, 1916. http://nzetc.victoria.ac.nz/tm/scholarly/tei-BesStor.html

Buchli, Victor An Anthropology of Architecture London: Bloomsbury, 2013.

Lyell, Charles The Geological Evidences of the Antiquity of Man, With Remarks of Theories of the origin of Species by Variation London: John Murray, 1863.

Sundt, Richard A. Whare Karakia: Maori Church Building \& Ritual in Aotearoa New Zealand, 1834-1863. Auckland: Auckland University Press, 2010.

Taylor, Richard "On New Zealand Lake Pas" Transactions and Proceedings of the Royal Society of New Zealand (1872) 5:101-102.

http://rsnz.natlib.govt.nz/volume/rsnz_05/rsnz_05_00_000610.html accessed 10 November 2014.

Taylor, Richard Te Ika a Maui, or New Zealand and its Inhabitants London: Wertheim and Mackintosh, 1870.

Vogt, Adolf Max Le Corbusier, the Noble Savage: Toward an Archaeology of Modernism Trans. Radka Donnell Cambridge, Massachusetts \& London, England: The MIT Press, 1998.

Maori Dictionary http://www.maoridictionary.co.nz Accessed 10 November 2014.

\section{Images}

de Sainson, Louis Auguste and Victor Adam Vue de l'Aiguade di Cap.ne
Cook, a Houahoua, [view of the watering place of Captain Cook, at Houahoua (Uawa - Tolaga Bay)] 1833 Auckland Art Gallery Toi o Tamaki Accession Number 2009/3/7

Keller, Ferdinand "The discovery of the lake dwellings in the Lake of Zurich" Mittheilungen der Antiquarischen Gesellschaft in Zürich (1854, 1858) https://media.istockphoto.com/illustrations/swiss-piledwellings-from-the-stone-age-illustrationid1255371161? $\mathrm{k}=20 \& \mathrm{~m}=1255371161 \& \mathrm{~s}=612 \times 612 \& \mathrm{w}=0 \& \mathrm{~h}=1 \mathrm{o} 84 \mathrm{zjapXAC}$ n2C14x6EVyY9D5YUk8H-iy3VaOSU0lic=

Taylor, Richard "Lake Buildings in Horowhenua" (1845) Alexander Turnbull Library Reference: E-296-q-092 